\title{
Efficacy of Bion, Amistar and Tilt in controlling brown spot and narrow brown spot of rice cv. BR11 (Mukta)
}

\author{
I. Hossain, P. Dey ${ }^{1}$ and M. Z. Hossain \\ Department of Plant Pathology, Bangladesh Agricultural University, Mymensingh-2202, Bangladesh \\ E-mail:dhossain69@gmail.com and ${ }^{1}$ Seed Pathology Centre, Bangladesh Agricultural University, Mymensingh-2202, \\ Bangladesh
}

\begin{abstract}
Efficacy of Bion (benzothiodiazole), Amistar (azoxystrobin) and Tilt (propiconazole) was evaluated for controlling Brown spot and Narrow brown spot of rice cv. BR11 (Mukta). Bion, Amistar and Tilt @ $50 \mathrm{mg} / \mathrm{L}, 1 \mathrm{ml} / \mathrm{L}$ and $1 \mathrm{ml} / \mathrm{L}$, respectively were sprayed at tillering and ear initiation stages that resulted in marked reduction of Brown spot and Narrow brown spot. Bion, Amistar and Tilt significantly increased number of grains/ear and number of healthy grains/ear by reducing number of diseased grains/ear. Bion, Amistar and Tilt resulted in 25.87, 32.17 and $26.76 \%$ higher grain yield, respectively over the untreated control when sprayed at tillering stage.
\end{abstract}

Keywords: Bion, Amistar, Tilt, Brown spot, Narrow brown spot, Rice cv. BR11

\section{Introduction}

Rice (Oryza sativa L.) is the most important food crop in the world and a primary food source for more than a third of world's population. It is the staple food in Bangladesh, but yield of this crop is comparatively lower than even neighbouring countries. At present the total annual rice production in the country is approximately 31.975 million tons (BBS, 2010). The rice culture is seriously affected by diseases over its whole cycle. Diseases can affect both productivity and grain quality as well (Santos et al., 2009). Among many constraints responsible for low yield of rice in Bangladesh, disease plays an important role, sometimes leading to disastrous consequences (Fakir, 1982). Out of 31 rice diseases, 10 are considered as major diseases (Miah et al., 1985; Shahjahan et al., 1987). Among the diseases, brown spot (Bipolaris oryzae) and narrow brown spot (Cercospora oryzae) cause substantial loss to rice both in quality and quantity. In the last decades, a number of systemic fungicides with different modes of action and targets have been applied to reduce the losses caused by the diseases (Pasquer et al., 2005). The common diseases of rice are being controlled specially by spraying fungicides that cause environmental pollution. The best way to combat plant diseases is to develop, boost and maintain disease resistance in the crop. The rice disease may be minimized or controlled through inducing resistance in plant. Some chemicals can be used as resistance inducer. Resistance inducing chemicals that are able to induce broad disease resistance offer an additional option for the farmer to complement genetic disease resistance and the use of fungicides (Oostendorp et al., 2001). Salicylic acid (White, 1979), 2.6-dichloroisonicotinic acid (Metraux et al., 1991), benzothiodiazole (Goerlach et al., 1996) were demonstrated as chemical agents for resistance inducer. Inducing resistance is a new concept in our country and attempt has been made to use chemicals as resistance inducer to rice. The present study was, therefore, designed to evaluate comparative efficacy of resistance inducer Bion with two chemicals viz. Amistar and Tilt for controlling brown spot and narrow brown spot diseases as well as on grain quality and yield of rice.

\section{Materials and Methods}

The experiment was conducted at the Field Laboratory, Department of Plant Pathology, Bangladesh Agricultural University, Mymensingh in 2001. A high yielding cultivar BR11 (Mukta) was selected for the study as test crop and seeds were collected from the BADC, Mymensingh Sadar. The experiment was carried out in Randomized Complete Block Design (RCBD) with 3 replications. The unit plot size was 10 $\mathrm{m}^{2}$. Normal agronomic practices and fertilization were used for the study as per recommendation (BRRI, 1999). Bion @ 50 mg/L, Amistar @ $1 \mathrm{ml} / \mathrm{L}$ and Tilt @ $1 \mathrm{ml} / \mathrm{L}$ were sprayed at tillering and ear initiation stages of rice. Only water was sprayed in case of control plots. 
Data were recorded at flowering and milking stages. Four leaves from the top of the plant were considered for grading (0-9 scale) the severity of diseases. Ten plants were randomly selected from each plot. The severity of two diseases viz. brown spot and narrow brown spot were recorded following Standard Evaluation System for Rice (IRRI, 1980).

The yield and yield contributing parameters viz. plant height $(\mathrm{cm})$, ear length $(\mathrm{cm})$, number of grains/ear, number of healthy grains/ear, number of spotted grains/ear, number of discoloured grains/ear, number of chaffy grains/ear, weight of healthy grains/ear, weight of grains/ear and yield of grains (t/ha) were recorded. All data were analyzed for evaluating test of significance.

\section{Results and Discussion}

At flowering stage, the severity of brown spot and narrow brown spot were insignificant among the treatments (Table 1) but at milking stage, all three chemicals reduced the incidence of the diseases. The highest severity was found in control plots. Spraying of Bion at ear initiation stage significantly reduced the incidence of narrow brown spot. Kumar and Ram Sing (2003) reported Propiconazol (Tilt) as the most promising fungicide that provided $47.5 \%$ and $26.5 \%$ reduction in disease incidence and severity, respectively along with $7.7 \%$ increase in grain yield. The authors further added that Propiconazole application at disease initiation, booting and flowering stages resulted in maximum disease control along with significant increase in grain yield followed by two sprays at disease initiation and booting stages.

Table 1. Effect of Bion, Amistar and Tilt on severity of Brown spot and Narrow brown spot of Rice cv. BR11 (Mukta) at flowering and milking stage

\begin{tabular}{|l|c|c|c|c|}
\hline \multirow{2}{*}{ Treatments } & \multicolumn{3}{c|}{ Disease severity grade (0-9 scales) } \\
\cline { 2 - 5 } & \multicolumn{2}{|c|}{ Brown spot } & \multicolumn{2}{c|}{ Narrow brown spot } \\
\cline { 2 - 5 } & $\begin{array}{c}\text { Flowering } \\
\text { stage }\end{array}$ & $\begin{array}{c}\text { Milking } \\
\text { stage }\end{array}$ & $\begin{array}{c}\text { Flowering } \\
\text { stage }\end{array}$ & $\begin{array}{c}\text { Milking } \\
\text { stage }\end{array}$ \\
\hline $\mathrm{T}_{1}=$ Bion @ 50mg/L applied at Tillering stage & 0.54 & 2.14 & 0.54 & 1.92 \\
\hline $\mathrm{T}_{2}=$ Bion @ 50mg/L applied at Ear initiation stage & 0.57 & 1.92 & 0.86 & 1.65 \\
\hline $\mathrm{T}_{3}=$ Amistar @1 $1 \mathrm{ml} / \mathrm{L}$ applied at Tillering stage & 0.87 & 1.64 & 0.65 & 1.99 \\
\hline $\mathrm{T}_{4}=$ Amistar @ 1 ml/L applied at Ear initiation stage & 0.59 & 2.12 & 0.65 & 2.13 \\
\hline $\mathrm{T}_{5}=$ Tilt @ 1 ml/L applied at Tillering stage & 0.60 & 1.44 & 0.74 & 2.05 \\
\hline $\mathrm{T}_{6}=$ Tilt @ 1 ml/L applied at Ear initiation stage & 0.57 & 1.94 & 0.84 & 1.80 \\
\hline $\mathrm{T}_{7}=$ Control (without chemical) & 1.16 & 2.89 & 0.97 & 2.80 \\
\hline LSD ( $\mathrm{p}=0.05$ ) & $\mathrm{NS}$ & 0.4673 & $\mathrm{NS}$ & 0.2813 \\
\hline
\end{tabular}

NS= Not significant

The treatments did not show any significant variation on plant height, ear length and discoloured grains/ear (Table 2). The plant height varied from 94.33 to $98.33 \mathrm{~cm}$ and ear length varied from 22.70 to $23.37 \mathrm{~cm}$. The highest number of grains/ear (179.00) and the highest number of healthy grains/ear (32.7) was found in plots where Amistar was sprayed at tillering stage and Bion sprayed at ear initiation stage, respectively. The lowest number of grains/ear and healthy grains/ear were found in control plot. In case of spotted grains/ear, the highest count (108.00) was made in Amistar @1ml/L applied at Tillering stage followed by Amistar @ $1 \mathrm{ml} / \mathrm{L}$ applied at Ear initiation stage. The number of unfilled grains/ear was highest in control plots, where the lowest was in Amistar @ $1 \mathrm{ml} / \mathrm{L}$ applied at Ear initiation stage. 
Table 2. Effect of Bion, Amistar and Tilt on plant growth and yield contributing characters in Rice cv. BR11 (Mukta)

\begin{tabular}{|c|c|c|c|c|c|c|c|}
\hline Treatments & $\begin{array}{c}\text { Plant } \\
\text { height } \\
(\mathrm{cm})\end{array}$ & $\begin{array}{c}\text { Ear length } \\
(\mathrm{cm})\end{array}$ & $\begin{array}{c}\text { No. of } \\
\text { grains/ear }\end{array}$ & $\begin{array}{c}\text { No. of } \\
\text { healthy } \\
\text { grains/ear }\end{array}$ & $\begin{array}{c}\text { No. of } \\
\text { spotted } \\
\text { grains/ear }\end{array}$ & $\begin{array}{c}\text { No. of } \\
\text { discoloured } \\
\text { grains/ear }\end{array}$ & $\begin{array}{c}\text { No. of } \\
\text { unfilled } \\
\text { grains/ear }\end{array}$ \\
\hline $\mathrm{T}_{1}$ & 97.67 & 23.1 & 170.3 & 29.7 & 104.3 & 6.7 & 29.7 \\
\hline $\mathrm{T}_{2}$ & 97.00 & 22.9 & 162.0 & 32.7 & 92.0 & 6.3 & 31.0 \\
\hline $\mathrm{T}_{3}$ & 98.33 & 23.4 & 179.0 & 30.7 & 108.0 & 7.7 & 32.7 \\
\hline $\mathrm{T}_{4}$ & 97.33 & 22.8 & 166.3 & 24.3 & 107.7 & 7.7 & 26.7 \\
\hline $\mathrm{T}_{5}$ & 94.33 & 23.4 & 176.7 & 31.3 & 105.0 & 8.3 & 32.0 \\
\hline $\mathrm{T}_{6}$ & 96.00 & 22.7 & 161.0 & 32.3 & 92.0 & 7.0 & 32.7 \\
\hline $\mathrm{T}_{7}$ & 94.67 & 22.7 & 157.0 & 20.7 & 77.0 & 5.3 & 53.7 \\
\hline LSD $(p=0.05)$ & $\mathrm{NS}$ & $\mathrm{NS}$ & 13.00 & 4.141 & 11.35 & $\mathrm{NS}$ & 5.77 \\
\hline
\end{tabular}

$\mathrm{T}_{1}=$ Bion @ 50mg/L applied at Tillering stage, $\mathrm{T}_{2}=$ Bion @ 50mg/L applied at Ear initiation stage,

$\mathrm{T}_{3}=$ Amistar @1 $\mathrm{ml} / \mathrm{L}$ applied at Tillering stage, $\mathrm{T}_{4}=$ Amistar @ $1 \mathrm{ml} / \mathrm{L}$ applied at Ear initiation stage

$\mathrm{T}_{5}=$ Tilt @ $1 \mathrm{ml} / \mathrm{L}$ applied at Tillering stage, $\mathrm{T}_{6}=$ Tilt @ $1 \mathrm{ml} / \mathrm{L}$ applied at Ear initiation stage,

$\mathrm{T}_{7}=$ Control (without chemical)

NS= Not significant

There were significant differences among the three chemicals used in respect of yield under different treatments (Table 3). In case of weight of grains/ear, the highest weight $(3.50 \mathrm{~g})$ was found in plots where Amistar was sprayed at tillering stage, but the lowest (2.93g) was found in control plot. In case of weight of healthy grains/ear, the highest weight $(0.98 \mathrm{~g})$ was found in plots where Bion was sprayed at ear initiation stage followed by plots where Tilt was sprayed at ear initiation stage. The grain yield under different treatments ranged from 4.60 to $6.08 \mathrm{t} / \mathrm{ha}$, where the highest and lowest grain yield were recorded in plot where Amistar was sprayed at tillering stage and in plots under control, respectively. Bion @ $50 \mathrm{mg} / \mathrm{L}$ applied at tillering stage was as good as Amistar in terms of weight of grains/ear, weight of healthy grains/ear and grain yield.

Table 3. Effect of Bion, Amistar and Tilt on grain yield in rice cv. BR11 (Mukta)

\begin{tabular}{|l|c|c|c|}
\hline Treatments & $\begin{array}{c}\text { Weight of } \\
\text { grains/ear }(\mathrm{g})\end{array}$ & $\begin{array}{c}\text { Weight of healthy } \\
\text { grains/ear }(\mathrm{g})\end{array}$ & Grain yeild (t/ha) \\
\hline $\mathrm{T}_{1}=$ Bion @ 50mg/L applied at Tillering stage & $3.26 \mathrm{abc}$ & $0.89 \mathrm{ab}$ & $5.79 \mathrm{ab}(25.87)$ \\
\hline $\mathrm{T}_{2}=$ Bion @ 50mg/L applied at Ear initiation stage & $3.07 \mathrm{bcd}$ & $0.98 \mathrm{a}$ & $5.19 \mathrm{c} \mathrm{(12.83)}$ \\
\hline $\mathrm{T}_{3}=$ Amistar @1ml/L applied at Tillering stage & $3.50 \mathrm{a}$ & $0.92 \mathrm{ab}$ & $6.08 \mathrm{a}(32.17)$ \\
\hline $\mathrm{T}_{4}=$ Amistar @ 1 ml/L applied at Ear initiation stage & $3.45 \mathrm{a}$ & $0.73 \mathrm{bc}$ & $5.44 \mathrm{bc}(18.26)$ \\
\hline $\mathrm{T}_{5}=$ Tilt @ 1 ml/L applied at Tillering stage & $3.55 \mathrm{ab}$ & $0.94 \mathrm{a}$ & $5.83 \mathrm{ab}(26.74)$ \\
\hline $\mathrm{T}_{6}=$ Tilt @ 1 ml/L applied at Ear initiation stage & $3.00 \mathrm{~cd}$ & $0.87 \mathrm{ab}$ & $5.20 \mathrm{c}(13.04)$ \\
\hline $\mathrm{T}_{7}=$ Control (without chemical) & $2.93 \mathrm{~d}$ & $0.62 \mathrm{c}$ & $4.60 \mathrm{~d}$ \\
\hline LSD (P=0.05) & 0.2869 & 0.1866 & 0.4904 \\
\hline
\end{tabular}

Data in column having common letter(s) do not differ significantly at $5 \%$ level of significance.

Data in parentheses indicate percent increase over control

The application of Bion, Amistar and Tilt at tillering stage increased yield by $25.87 \%, 32.17 \%$ and $26.74 \%$, respectively over control. Aminuzzaman and Hossain (2007) reported that seed treatment with Bion and Amistar increased 53.33 and $53.00 \%$ grain yield, respectively of wheat over untreated control. From the study it may be concluded that Bion, Amistar and Tilt can be applied successfully for controlling brown spot and narrow brown leaf spot. It can be concluded that Bion @ 50mg/L applied at tillering stage showed excellent performance as resistance inducer. 


\section{References}

Aminuzzaman, F.M. and Hossain, I. 2007. Evaluation of plant activator and chemical fungicides on leaf blight (Bipolaris sorokiniana) development and yield of wheat. Pak. J. Biol. Sci., 10: 1797-1803.

BBS (Bangladesh Bureau of Statistics). 2010. Statistical pocket book Bangladesh. Bangladesh Bureau of Statistics, Stat. Div., Minis. Plan., Govt. People's Repub. Bangladesh. February 2011. p.207.

BRRI (Bangladesh Rice Research Institute). 1999. Modern Rice Cultivation (Bengali Bulletin), Bangladesh Rice Res. Inst., Gazipur, p.26.

Fakir, G.A. 1982. An annoted list of seed borne diseases in Bangladesh.

Gaerlach, J., Volrath, S., Knauf-Beiter, G., Hengy, G., Beckhove, U., Kogel, K.H., Oostendrop, M., Stub, T., Ward, E., Kessmann, H. and Ryals, J. 1996. Benzothiodiazole, a novel class of inducers of systemic acquired resistance, activates gene expression and disease resistance in wheat. Plant cell 8: 629-643.

IRRI (International Rice Research Institute). 1980. Standard evaluation system for rice. IRRI: Los Banos, Philippines.

Kumar, A., Ram-Sing and Jalali, B.L. 2003. Management of stem rot of rice with resistance inducing chemicals and fungicides. Indian - Phytopathology. Haryana Agricultural University, India. 56(3):266-269.

Metraux, J.P., Ahl-Goy, P., Staub, T., Speich, J., Steinemann, A., Ryals, J. and Ward, E. 1991. Induced systematic resistance in cucumber in response to 2,6-dichloro-isonicotinic acid and pathogens. Pages 432-439 in: Advances in Molecular Genetics of Plant-Microbe Interactions. Vol. 1. H. Hennecke and D.P.S. Verma, eds. Kluwer Academic Publishers, Dordrecht, the Netherlands.

Miah, S.A., Shahjahan, A.K.M., Hossain, M.A. and Sharma, N.R. 1985. Survey of rice disease in Bangladesh. Trop. Pest Management. 31 (3): 208-213.

Oostendorp, M., Kunz, W., Dietrich, B. and Staub, T. 2001. Induced disease resistance in plants by chemicals. European Journal of Plant Pathology. 107(1): 19-28.

Pasquer, F.E., Isdore, J. Zarn and Keller, B. 2005. Specific patterns of changes in wheat gene expression after treatment with three antifungal compounds. Plant Mol. Biol., 57: 693-707.

Santos, G.R. dos., Castro-Neto, M.D., Ignacio, M., Furtado, G.Q., Rancel, P.H.N., Silva, L.M. and Riveiro, F.F. 2009. Registance of upland rice genotypes to rice disease at the south of Tocantins State. Bioscience Journal. 25(6): 96 -105.

Shahjahan, A.K.M., Duve, T. and Bonman, J.M. 1987. Climate and rice disease. In weather and rice. IRRI, Los Banon, Lequa, Philippines. pp. 125-128.

White, R.F. 1979. Acetylsalicylic acid induces resistance to tobacco mosaic virus in tobacco. Virology 99: 410-412. 